\title{
COMPARATIVE SURVIVAL AND GROWTH OF FIVE CONIFERS RIDGE-PLANTED ON A WET SITE
}

\author{
By J. D. MacARTHUR ${ }^{1}$
}

\begin{abstract}
Five-year results indicate that ridge-planting is effective in reforesting poorlydrained land in the Morgan Arborteum. White, red, black, and Norway spruce and white pine showed significantly better survival and growth on ridges than in control planting. Norway and black spruce and white pine were the most successful. White spruce and red spruce survived well, but grew slowly.
\end{abstract}

\section{INTRODUCTION}

In reforesting wet sites the major problem is to find a suitable method of establishment-site preparation plus planting method-at reasonable cost. An additional, but secondary problem is the choice of species. In some situations climatic and market factors could restrict the usable species to one, or two, at most. Usually, the best approach would be to develop a method of establishment favouring tree growth generally with the intention of using several species interchangeably as desired.

Wet sites might be prepared by ditching, but ditches are expensive to dig and maintain. Furthermore they may restrict movement through the plantation and disposal of the soil removed presents an additional problem. An alternative method of preparation is the construction, by ploughing, of low ridges on which planted trees enjoy a more favourable moisture regime. Moreover, the ploughed furrows may improve run-off drainage of the site. With ridges there is no maintenance, no soil disposal problem, and they also provide a partial escape from weed competition. Consequently this preparation should favour a number of species.

Ridge-planting probably deserves more attention, particularly as an alternative to the commonly practised furrow planting. While on dry sites furrow planting has given good results (Cayford and Jarvis 1963) it may lead to trouble elsewhere. On thin soils it places roots below the richest soil, on wet sites in more frequently saturated soil, and, where other vegetation is present, furrow planting always places planted trees at a competitive disadvantage.

Wet sites have usually been ignored in favour of more suitable areas that are extensive enough to absorb all of the reforestation effort. However, in North

\footnotetext{
${ }^{1}$ Forester, Dept. of Woodlot Management, Macdonald College, P.Q.
} 
America some work has been done on this, and the similar problem of overcoming strong competition from herbaceous vegetation using both mound and ridge planting. In Wisconsin Stoeckeler (1947) observed better eight-year survival and growth of five species (white, Norway, and black spruce, white pine, white ash) ${ }^{2}$ planted on the plough layer than in either furrows or scalps. He attributed these results to 1) better aeration, 2) better drainage, 3) less burial by soil washing, 4) higher fertility from a double layer of organic matter, 5) less frost heaving, and 6) less smothering by competing vegetation. In New Brunswick McLeod (1946) reported better survival and growth of white spruce planted on raised ridges than on control plots on a periodically flooded site. He observed that ridges were better drained and competing vegetation less vigorous. In an Ontario experiment comparing growth and survival of white spruce planted on the plough layer and in the furrow, on a sandy site with a high water table, eight-year survival was similar but growth was significantly greater on the plough layer (Armson, 1958). It was noted that the rooting zone of furrow planted trees was periodically saturated with water, a probable cause of slower growth. In Quebec moundplanting of Norway spruce gave much better survivial and growth than furrow, scalp, low ridge, or control methods (MacArthur, 1964). In this study retarded drainage was probably secondary to competition from herbaceous plants.

While large scale ridge planting is not yet common in North America it has been used for many years in Britain as a means of reforesting peat. Ridging on peat has a long history of trial and error, and, more recently, experimentation including use of fertilizers and methods are still evolving (Zehetmayr, 1954).

In 1959 an experiment in ridge planting on a poorly-drained site was initiated in the Morgan Arboretum at Macdonald College, P.Q. Five species (white, black, red and Norway spruce and white pine) were involved in a study of survival and growth differences between ridge and non-ridge (control) planting. The experiment was initially reported by Jones (1963) and this paper presents and discusses significant and interesting five-year results.

\section{Methods and Materials}

The planting site was a formerly cultivated field that had begun to revert to forest until cleared of grey birch, aspen, and willow during the summer of 1955. After clearing the area was ploughed and then periodically disced to keep down vegetation until the experiment began in 1959. The soil is a St. Amable loamy sand, free of stones, over St. Rosalie clay. The clay impedes drainage and the site is usually wet, and periodically flooded, despite old farm ditches running through the generally flat area. Soil $\mathrm{pH}$ is 5.0 to 5.5 .

Details regarding planting stock (Table 1) show variation in size between species and lack of precise information as to origin. Size differences between species were unavoidable but were limited within species by pre-planting grading.

"Nomenclature as in "Native Trees of Canada", 6th ed., 1961. 
TABLE 1

Source and Characteristics of Planting Stock

\begin{tabular}{|c|c|c|c|c|c|}
\hline Species & Number & Age & \multicolumn{2}{|c|}{ Height-1960 } & Supplied by \\
\hline White pine & 150 & $3-0$ & \multicolumn{2}{|c|}{5.5 inches } & $\begin{array}{l}\text { Lands and Forests, Ont. } \\
\text { Orono }\end{array}$ \\
\hline White spruce & 150 & $3-0$ & 6.2 & " & $\begin{array}{l}\text { Lands and Forests, Ont. } \\
\text { Orono }\end{array}$ \\
\hline Black spruce & 150 & $\begin{array}{l}\text { variable } \\
5 \text { yrs. }\end{array}$ & 11.3 & $"$ & C.I.P., Clova, P.Q. \\
\hline Red spruce & 150 & $3-1$ & 6.5 & $"$ & $\begin{array}{l}\text { Lands and Forests, Ont. } \\
\text { Kemptville }\end{array}$ \\
\hline Norway spruce & 150 & $3-2$ & 11.1 & $"$ & $\begin{array}{l}\text { Dept. of Forestry, } \\
\text { Valcartier Forest Experiment } \\
\text { Stn. }\end{array}$ \\
\hline
\end{tabular}

Pairs of furrows were ploughed back to back in the fall of 1959 to form ridges about 6 inches high and 16 inches wide. These were spaced 14 feet apart leaving room between for control rows. Along both sides of each ridge ploughing resulted in shallow ditches. In May 1960 the trees were handplanted seven feet apart along the ridges and similarly in the intervening control rows.

The experimental arrangement was a randomized block of five main (species) plots replicated three times. Each main plot was subdivided into ridge and control planting. Of the 50 trees per main plot, 25 were ridge; and 25 controlplanted. Species were assigned at random to main plots by block but, because of ridge-making limitations, the ridge and control plantings were not randomized. However, since the topography of the site was regular and the rows ran across it this deficiency could have had little effect on the results. Blocks, on the other hand, were established along the topography to minimize within-block variation. Following planting competing vegetation was kept down by regular mowing. Each autumn the surviving trees were counted and measured for height.

\section{REsUlts}

Differences in survival between ridge planting and controls were highly significant by 1964 with ridge planting always superior. Differences between species were not significant, nor was there any significant species-method interaction.

Survival patterns for species and methods from 1960 to 1964 (Fig. 1.) illustrate trends during the early years of the experiment. All four spruces had similar high survival rates on ridges until 1964, but white pine survival, high until 1962, dropped sharply in 1963 and even more in 1964.

In the controls, white, black, and Norway spruce, appear to share a pronounced first season mortality, while red spruce and white pine have more 

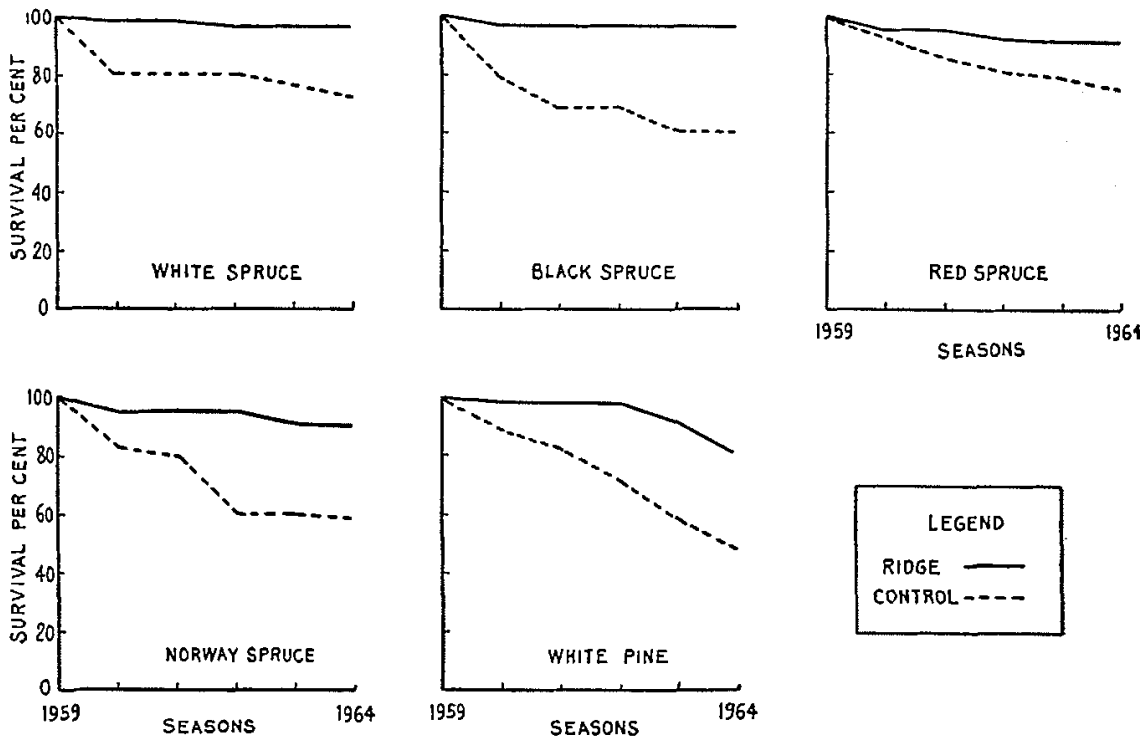

FIGURE 1. Per Cent Survival by Species and Planting Method - 1960 to 1964.

regular trends throughout the period. Survival differences between ridge planting and controls were least with red spruce and greatest with black spruce, a somewhat surprising result.

By 1964 size differences were significant at the 1 per cent level between methods, and at the 5 per cent level between species. Again there was no significant interaction between species and methods.

Growth patterns from 1962 to 1964 (Fig. 2) show that differences in size between ridge-planted and control trees developed along similar lines for all species. Initial size differences between species are indicated by the points of origin of the trend lines. Black and Norway spruce were significantly larger when planted than the other three species and remained larger than white and red spruce to the end of the period. However, by 1964 white pine had made up for its initial size disadvantage. In 1964 the five species could be placed in two size classes; black and Norway spruce and white pine in the larger; and white and red spruce in the smaller group, with only between-group differences significant.

\section{Discussion and Conclusions}

Five-year survival on ridges ranged from a low of 80 per cent for white pine to a high of 96 per cent for white and black spruce. Spruce survival, which ranged from 90 to 96 per cent, was excellent. White pine, however, with 

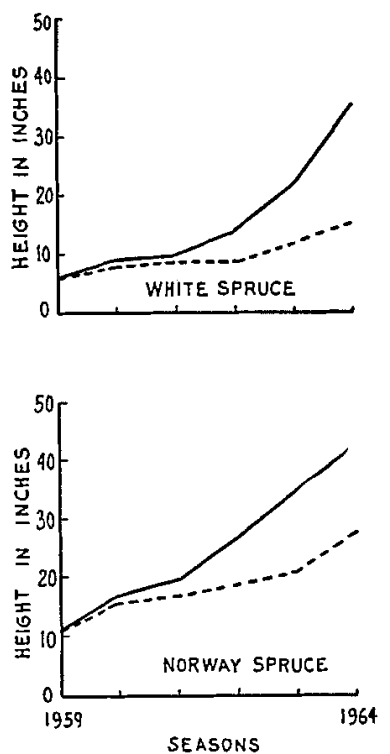
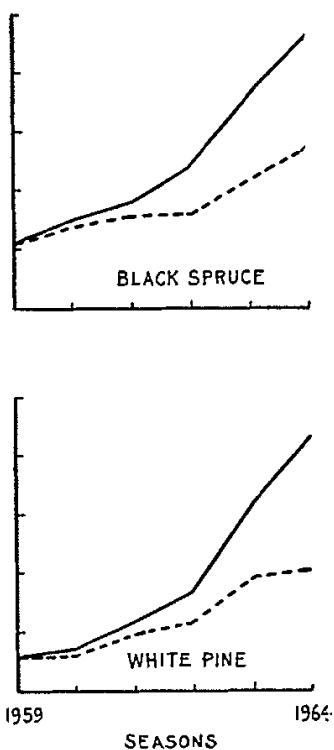
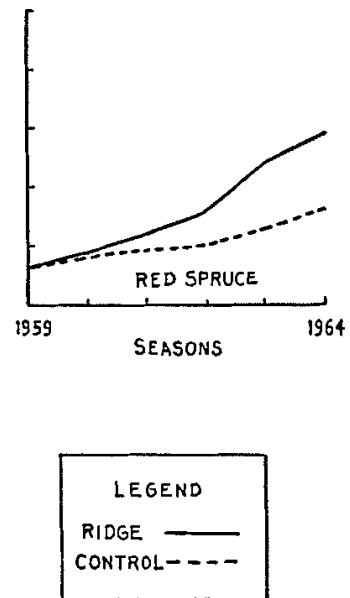

FIGURE 2. Growth by Species and Planting Method - 1960 to 1964.

survival already down to 80 per cent and with mortality apparently increasing, appears to be behaving differently. Some pine losses have been caused by blister rust but this does not account for the different trend. Between species differences are to be expected and would probably show up first between pine and spruce, and possibly later between the different spruces. Regarding the generally better survival on ridges, it should probably be recognized that improved drainage might not have been the only factor involved. Better nutrition and aeration, and particularly less frost-heaving, could have contributed. It should also be noted that the levels of survival indicated for controls are held up by the inclusion of many trees, particularly red and white spruce, that have only survived thus far because of the mowing of competing vegetation.

Growth on the ridges was also greater for all species. Again, improved drainage cannot be taken as the only contributing factor. Better aeration, less frost-heaving, and particularly better nutrition, may have been involved. Growth rates on the ridges have not been spectacular, except in contrast to those in controls, but are acceptable for such a site even for the relatively slowgrowing red and white spruce.

So far black spruce, Norway spruce, and white pine are the best species in this test, but future developments could change this assessment. Black spruce has exhibited the best combination of survival and growth, closely followed by Norway spruce and white pine. White pine growth has been reduced by while pine weevil damage but so far only slightly. In terms of survival and 
growth all five species have been satisfactory on ridges and unsatisfactory in controls for the first five years.

Ridge-planting of conifers appears to have considerable promise for sites that:

1. are poorly drained

2. are occupied by dense, herbaceous vegetation

3. present any combination of 1 and 2 .

However, the term of observation has been short and some important questions remain to be answered. Ridge-planting obviously improves early survival and growth, but as time passes and trees grow larger, new problems mayl arise.

So far ridge-planting has been considered as means of overcoming poor drainage or heavy competition, but other applications may also be possible. It might be an effective means of concentrating fertility in poor soils to improve survival and growth. Ridge-planted trees, particularly the hardwoods, might be less subject to girdling by rodents. In Christmas tree production ridging might provide a means of using sites normally too wet or too poor, especially if more than one crop of trees could be produced on the same set of ridges.

For ridge planting to be used extensively mechanization is necessary. As presently executed it is slow and expensive, but the history of the development of planting machines and their adaptation to special circumstances (Trenk, 1963) suggest that ridge-planting by machine would be possible. Perhaps a machine to make ridges and plant trees in one pass could be designed.

\section{ACKNOWLEDGEMENTS}

The author wishes to thank Dr. G. F. Weetman, Mr. A. G. Racey, and Professor A. R. C. Jones for their helpful criticisms and comments. He also acknowledges that the experiment reported upon was designed and initiated by Professor A. R. C. Jones.

\section{REFERENCES}

ARMSON, K. A. 1958. The effect of two planting methods on the survival and growth of white spruce (Picea glauca (Moench) Voss) in Eastern Ontario. For. Chron. 34 (4).

CAYFORD, J. H. and J. M. JARVIS. 1963. Furrowing and sheltering to improve early survival of planted red pine on dry sites, southeastern Manitoba. Tree Planter's Notes No. 59.

JONES, A. R. C. 1963. Dept. of Woodlot Management Annual Report 1962-63. pp. 52-55. Macdonald College, P.Q.

MAcARTHUR, J. D. 1964. Planting methods to overcome strong competition from dense, herbaceous vegetation. Tree Planters' Notes No. 66.

McLEOD, J. W. 1964. Planting white spruce on wet brushy land. Canada, Dept. of For., For. Res. Br., Dept. of For. Pub. No. 1067.

STOËCKELER, J. H. 1947. Planting poorly-drained wet sites. U.S.D.A., For. Ser, Lake States For. Exp. Sta, Tech. Note No. 276.

TRENK, FRED B. 1963. Evolution of modern tree planting machines. Jour. of For. Vol. $61(10): 726-730$.

ZEHETMAYR, J. W. L. 1954. Experiments in tree planting on peat. For. Comm. Bull. No. 22. 